\title{
Cross-cultural Corporate Identity Curriculum Model: A Needs Analysis
}

Nik Narimah Nik Abdullah, Nurfaradilla Mohamad Nasri, Muhammad Helmi Norman, Juritah Misman

To Link this Article: http://dx.doi.org/10.6007/IJARBSS/v11-i12/11759

DOI:10.6007/IJARBSS/v11-i12/11759

Received: 14 October 2021, Revised: 16 November 2021, Accepted: 30 November 2021

Published Online: 19 December 2021

In-Text Citation: (Abdullah et al., 2021)

To Cite this Article: Abdullah, N. N. N., Nasri, N. M., Norman, M. H., \& Misman, J. (2021). Cross-cultural Corporate Identity Curriculum Model: A Needs Analysis. International Journal of Academic Research in Business and Social Sciences, 11(12), 204-221.

Copyright: (C) 2021 The Author(s)

Published by Human Resource Management Academic Research Society (www.hrmars.com)

This article is published under the Creative Commons Attribution (CC BY 4.0) license. Anyone may reproduce, distribute, translate and create derivative works of this article (for both commercial and non0-commercial purposes), subject to full attribution to the original publication and authors. The full terms of this license may be seen at: http://creativecommons.org/licences/by/4.0/legalcode

Vol. 11, No. 12, 2021, Pg. $204-221$

Full Terms \& Conditions of access and use can be found at http://hrmars.com/index.php/pages/detail/publication-ethics 


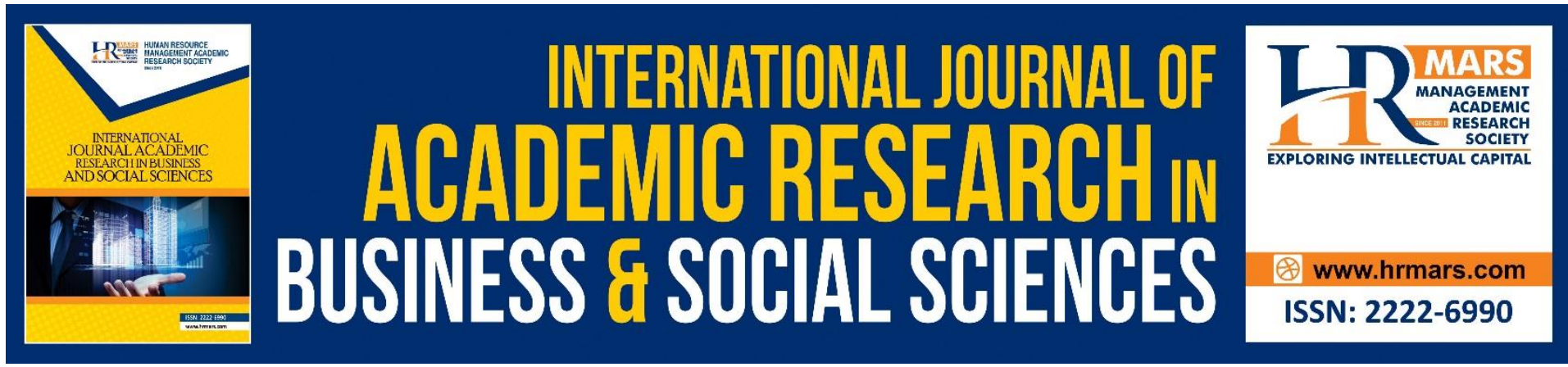

\title{
Cross-cultural Corporate Identity Curriculum Model: A Needs Analysis
}

\section{Nik Narimah Nik Abdullah, Nurfaradilla Mohamad Nasri, Muhammad Helmi Norman, Juritah Misman}

Faculty of Education, Universiti Kebangsaan Malaysia, 43600 Bangi, Selangor, Faculty of Art And Design, Universiti Teknologi MARA, 78000 Alor Gajah Melaka, Academy of Language

Studies, Universiti Teknologi MARA, 78000 Alor Gajah Melaka, Malaysia

Email:p92532@siswa.ukm.edu.my,nurfaradilla@ukm.edu.my, helmi.norman@ukm.edu.my, juritah744@uitm.edu.my

\begin{abstract}
Current study curriculum for Arts and Design lack emphasis towards preparing students with creativity and skills to face the challenges of 21st century education and industrial environment. The main objective of this study is to investigate a needs analysis for the Graphic Design Program in higher learning institutions based on a cross-cultural corporate identity curriculum model. Needs analysis is one of the most essential stages of data collection in order to provide information for systematic analysis. Generally, the study involved a semistructured interview conducted on twelve participants. Qualitative analysis of data was gathered from the semi-structured interviews and later transcribed and analyzed thematically. Three main themes were recorded: (i) design based on local cultural identity, (ii) cross-cultural curriculum and (iii) student-centered teaching and learning. Data findings concluded that the majority of the study participants were inclined towards a cross-cultural corporate identity curriculum model for the Graphic Design Program. It could be concluded that the proposed development of a cross-cultural corporate identity design curriculum in the Graphic Design Program was supported and approved by almost all study participants in this research. This study could contribute towards guiding and shaping technical academic courses that match 21st century needs.
\end{abstract}

Keywords: Corporate Identity, Cross-Cultural, Curriculum, Graphic Design Program, Needs Analysis

\section{Introduction}

The development of a cross-cultural corporate identity curriculum model for the Graphic Design Arts Program is a curriculum model which applies cross-cultural in the context of teaching and learning to produce corporate identity design. This model is intended as a guide for curriculum designers in developing a curriculum design which incorporates cultural or cross-cultural for Graphic Design Arts courses for higher learning institutions. Higher learning institutions are a platform in preparing students to perform effectively in a multiracial society (Dalib et al., 2019) and to provide an appropriate learning design 
experiences (Chiang et al., 2018). To ensure that the design of this curriculum model is pertinent to current needs in the creative industry, a needs analysis study is conducted. Essentially, needs analysis is the first step to understand about the culture of the community and identify the level of knowledge available before initiating the selection of objectives in the development of curriculum design (Thiruvengadam, 2014). A needs analysis is needed to ensure of the development of a learning program or curriculum which is more relevant to the needs of a certain area (Bocanegra-Valle \& Table, 2016). After identifying the needs analysis, the next step is to transform the needs into a form of learning objectives which would be the basis for the development of teaching and learning strategies, production of teaching content and also as an assessment instrument.

Culture is an important element in the planning or development aspect of curriculum design especially to develop the content of each curriculum (Murdoch-Kitt \& Emans, 2014). This is because part of the essence in education is to form an understanding and appreciation of the cultural heritage of the community to the younger generation (Nordin, 2018). Therefore, studies conducted by (Lee et al., 2016) have suggested that curriculum planning and development should strive to integrate cultural component as it is part of the essence of education to ensure that society benefit from it. Apart from that, to stimulate students' attention, curricular integration should include activities such as interactive learning and the use of information and communication technology (Rashed et al., 2020).

\section{Curriculum Development in Graphic Design Education}

Generally, curriculum development is implemented to produce a knowledgeable and skilled society which in turn could meet the needs of the creative industry (Austerlitz et al., 2008; Orr and Shreeve, 2018). In fact, curriculum development which meets the needs of the industry is very important for the Graphic Design Program. (Fraher \& Martinson, 2011) also stressed that students of the Graphic Design Program are in dire need of education that meets the needs of the industry because it will provide real experience as what is needed in the actual work industry as professional designers. Thus, the curriculum for the Graphic Design Program needs to be developed in line with the role played in the creative field (Drucker, 2016). According to (Drucker, 2016) one of the important features in the development of Graphic Design Program curriculum design is the emphasis on the formation of good understanding to convey information effectively and meet the needs of society. (Drucker, 2016) added that the curriculum of the Graphic Design Program should focus on technical aspects and the outcome in the production of a design.

In fact, the graphic design field comprises various components which serve as a platform to produce creativity. Corporate identity is one of the components in the Graphic Design Program offered at the diploma or degree levels in local higher learning institutions. Corporate identity in the field of education is an introductory course on basic work of graphic design such as logos and corporate items, packaging, souvenirs, promotional materials, website development and more. In addition, corporate identity is also a majoring in the final year project for students in the Graphic Design Program at local higher learning institutions. Basically, learning in producing corporate identity design requires mastery of knowledge of design basics such as concept selection, colour use, typography and technology use skills (Foroudi et al., 2017). For instance, as a graphic designer, the basic understanding and skills of producing designs are formed through the mastery of basic designs such as the production of logos in corporate identity. The design aspect of a logo has its own unique message or 
value, its meanings can be linked to the local sociocultural environment it symbolizes (Yunus et al., 2019). The production of corporate identity designs is very important because it reflects the identity or image of a company, organization or product that is shown to the public (Grethe \& Pedersen, 2016).

There are several important aspects that need to be emphasized in developing curriculum design as recommended by previous researchers. Due to this, this study proposes a look into the needs analysis towards a new curriculum development design in Graphic Design Program based on a cross-cultural-based curriculum. Cross-cultural in learning produces design which encourages students to better understand about the different cultures and in turn could inspire new ideas which could be applied in the process of producing a design (Lee \& Bain, 2016). In addition, (Hoyos et al., 2015) also have a similar view that understanding of culture can help increase understanding of cultural differences and this is very important for a designer to remain competitive globally. Cross-cultural in teaching and learning also can help students from many cultures to communicate effectively (Ahmad \& Weerakkody, 2011).

The advantages of various ethnicities and cultures give inspirations towards the emergence of the production of various unique and creative designs. A study conducted by (Lee \& Bain, 2016), also suggested that the field of design education could apply culture in the context of learning in order to meet and satisfy the needs of the target group. In the context of cross-cultural design education, there is still limited discussion in the form of empirical studies (Lee et al., 2016). Cross-cultural aspects need to be applied in the learning of design to increase awareness of the diversity of unique sources of ideas via cultural diversity. Therefore, this needs analysis study was conducted to identify cross-cultural needs in the development of cross-cultural corporate identity design curriculum for Graphic Design Program at diploma level. Therefore, the development of this cross-cultural corporate identity design curriculum is seen to give new life to the Graphic Design Program curriculum.

\section{Need Analysis}

The cross-cultural corporate identity curriculum is new curriculum development for the Graphic Design Program. The corporate identity curriculum needs to be reformed in order to adapt to the current situation and needs. This study was conducted to obtain direct first-hand information from lecturers and graphic designers on the need for a cross-cultural corporate identity curriculum. This proposed curriculum development study integrates local cultural elements and applies a project-based learning environment. Project-based teaching and learning is an appropriate mechanism to be practiced in graphic design education (Orr et al., 2014). To develop the new curriculum, this research applies design and development research approaches (Richey et al., 2004). Based on the research of several previous studies, the concept of development in education is a form of production of a learning material (Sahrir et al., 2012). While the definition of research and development carries the meaning of research conducted systematically and through several phases such as design, development and evaluation (Ibrahim, 2016; Richey \& Klein, 2005).

Generally, there are three main phases in design and development research namely:

Phase one: Needs analysis phase

Phase two: Development and design phase

Third phase: Evaluation phase 
Nevertheless, this study will focus only on Phase one which is the needs analysis phase. According to (Bocanegra-Valle \& Table, 2016), needs analysis is a form of information gathering and systematic analysis in the development of a sustainable curriculum. The purpose of the implementation of needs analysis is to gather information to develop all types of teaching and learning so that the programs offered are more relevant to current needs (Thiruvengadam, 2014) . The view by (Al-hamlan, 2015) states that needs analysis is defined as a specific platform that can be used for improvement in the academic field. Therefore, in this study, a needs analysis was conducted to obtain the views of a group of educators and graphic designers on the reforms or improvements that can be implemented in the development of cross-cultural corporate identity curriculum design.

In the context of this study, needs analysis was conducted to answer the research questions namely:

What is the need for the construction of a cross-cultural corporate identity curriculum in the Graphic Design Program?

Finally, the findings of needs analysis were evaluated. The results of the study would be useful for the design development of main components and elements for each main component of the cross-cultural corporate identity curriculum. Ultimately, this study could also empower graduates to thrive amidst the rapid changes in the graphic design academic and professional field.

\section{Research Problem}

Graphic Design programs largely develop curriculum design according to the planning of their respective educational institutions. Notably, there might be certain institutions that would lack the experiences in the development of graphic design; and as an outcome the graduates produced would not be able to meet the needs of the creative industry. A study by (Spencer, 2016), also reported that Graphic Design Arts Program at the university level is less successful to produce graphic design arts students according to current needs and have caused graphic arts graduates to have difficulty getting jobs as designers in the industry. Similarly, (Meyer \& Norman, 2020) also stated that the current design education system is less skilled in preparing or empowering students to face the challenges of the 21st century. This means that the main design foundations and the design process are less emphasized in the teaching and learning approaches, despite the fact that skills for the development of creative ideas for solving problems or issues in complex designs are very essential for young designers. Based on several previous studies, there are several factors that have been known to be the cause of the problem, among them is the problem of implementation of teaching and learning methods that is no transformation in the Graphic Design Program because there are academics who still practice teaching and learning methods that do not meet the demands and needs of the current environment (Blair-early, 2010; Drucker, 2016; Ozkaynak \& Ust, 2012). In addition, in the study (Inciong, 2010) stated that in-depth discussion of the assigned tasks and emphasis on the design production process is given less attention in terms of learning graphic design. Some of the learning issues highlighted by (Meyer, 2008) in previous studies include the problem of students' understanding of cultural components in society, different teaching and learning practices in learning about culture and most learning is too dependent on certain cultural aspects even though they have a basic understanding of multiculturalism.

In addition, there are some recent studies which state the need for the application of culture in Graphic Design Program. Among them is a study conducted by (Yang \& Hsu, 2017) 
which emphasizes that Graphic Design Program is very important for cultural development in society. Although cross-cultural is not a new thing in the field of education, but in a study conducted by (Gray \& Boling, 2017) stated that the influence and elements of cross-cultural are less practiced in the production of designs. The findings of the study (Offorma, 2016), suggest that curriculum development should integrate cultural components that are the essence of education so that teaching approaches become more meaningful. Educators need to strengthen their knowledge of racial culture so that the knowledge can be channelled to students more effectively (Hie et al., 2018). Therefore, based on the research gap which has been identified then this study is important to explore the development needs of crosscultural corporate identity curriculum design for Graphic Design Program.

The objective of the study is to identify the need for the development of a cross-cultural corporate identity design curriculum in the Graphic Design Program. In the context of this study, the implementation of needs analysis is aimed towards identifying the views and knowledge of study participants consisting of lecturers as well as graphic designers who have extensive experience in the field of graphic design on cross-cultural corporate identity. Semistructured interview techniques were conducted to answer the research questions, namely: What are the needs in the development of a cross-cultural corporate identity design curriculum for Graphic Design Program?

The questions of this study provided insights into the views of the study participants on the following:

a) cross-cultural needs in the production of graphic design artwork

b) cross-cultural corporate identity curriculum requirements in Graphic Design Program

c) appropriate teaching and learning methods for cross-cultural corporate identity curriculum in graphic design program

\section{Research Method}

Needs analysis can be implemented using qualitative or quantitative approach by using suitable instruments including interviews or questionnaires (Chu, 2016). This study applied a qualitative approach to identify cross-cultural needs in the context of teaching and learning, especially to generate corporate identity design. Data collection involved interviews with experts in the Graphic Design academic field and also professional graphic designers.

\section{Participants}

Semi-structured interviews were used for data collection involving a total of 12 participants comprising of 10 lecturers who have had teaching experiences from at least three to twenty years in the Graphic Design Program in local institutions of higher learning and also 2 graphic designers from the public sector who have had experiences of sixteen to twenty years in producing professional graphic designs. Interviews were done in Malay according to the participants' language preference which was the Malay language and was translated to English when reporting was done in this journal article. Table 1 showed the background of the study participants involved in this study. Overall, the selected participants were individuals who have had extensive knowledge in design education especially graphic design; and they have experiences in the production of graphic design works. Altogether, 12 people were involved with 6 men and 6 women from various ages and races representing the majority races in Malaysia ranging of Malays, Chinese and Indians. The rationale for the selection of the study participants who are of various races and have different work experiences is to obtain diverse information which is seen appropriate to the context of the study which is 
based on a cross-cultural graphic design context. The number of participants selected in this study is based on purposive sampling. Therefore, the selection of study participants is based on suitability to the context and the purpose of the study.

Table 1: Study Participants' Background Information

\begin{tabular}{|c|c|c|c|c|c|c|}
\hline $\begin{array}{l}\text { STUDY } \\
\text { PARTICIPANT }\end{array}$ & AGE & GENDER & POSITION & $\begin{array}{l}\text { SERVICE } \\
\text { PERIOD }\end{array}$ & $\begin{array}{l}\text { WORK } \\
\text { PLACE }\end{array}$ & RACE \\
\hline P1 (participant 1) & $25-35$ & Male & $\begin{array}{l}\text { Graphic } \\
\text { Lecturer }\end{array}$ & $5-10$ & $\begin{array}{l}\text { Public } \\
\text { University }\end{array}$ & Malay \\
\hline P2(participant 2) & $46-55$ & Female & $\begin{array}{l}\text { Graphic } \\
\text { Lecturer }\end{array}$ & $16-20$ & $\begin{array}{l}\text { Private } \\
\text { University } \\
\text { College }\end{array}$ & Indian \\
\hline P3(participant 3) & $25-35$ & Male & $\begin{array}{l}\text { Graphic } \\
\text { Lecturer }\end{array}$ & $11-15$ & $\begin{array}{l}\text { Private } \\
\text { University } \\
\text { College }\end{array}$ & Chinese \\
\hline P4 (participant 4) & $36-45$ & Female & $\begin{array}{l}\text { Graphic } \\
\text { Lecturer }\end{array}$ & $11-15$ & $\begin{array}{l}\text { Private } \\
\text { University } \\
\text { College }\end{array}$ & Malay \\
\hline P5 (participant 5) & $46-55$ & Female & $\begin{array}{l}\text { Graphic } \\
\text { Lecturer }\end{array}$ & $16-20$ & $\begin{array}{l}\text { Public } \\
\text { University }\end{array}$ & Malay \\
\hline P6 (participant 6) & $25-35$ & Male & $\begin{array}{l}\text { Graphic } \\
\text { Lecturer }\end{array}$ & $3-5$ & $\begin{array}{l}\text { Public } \\
\text { University }\end{array}$ & Malay \\
\hline P7 (participant 7) & $46-55$ & Female & $\begin{array}{l}\text { Graphic } \\
\text { Lecturer }\end{array}$ & $11-15$ & $\begin{array}{l}\text { Private } \\
\text { University } \\
\text { College }\end{array}$ & Chinese \\
\hline P8 (participant 8) & $25-35$ & Male & $\begin{array}{l}\text { Graphic } \\
\text { Lecturer }\end{array}$ & $5-10$ & $\begin{array}{l}\text { Private } \\
\text { University } \\
\text { College }\end{array}$ & Malay \\
\hline P9 (participant 9) & $36-45$ & Female & $\begin{array}{l}\text { Graphic } \\
\text { Lecturer }\end{array}$ & $11-15$ & $\begin{array}{l}\text { Public } \\
\text { University }\end{array}$ & Malay \\
\hline $\begin{array}{l}\text { P10 (participant } \\
\text { 10) }\end{array}$ & $25-35$ & Male & $\begin{array}{l}\text { Graphic } \\
\text { Lecturer }\end{array}$ & $5-10$ & $\begin{array}{l}\text { Public } \\
\text { University }\end{array}$ & Malay \\
\hline $\begin{array}{l}\text { P11 } \\
\text { 11) }\end{array}$ & $46-55$ & Male & $\begin{array}{l}\text { Graphic } \\
\text { Designer }\end{array}$ & $16-20$ & $\begin{array}{l}\text { Creative } \\
\text { Industry }\end{array}$ & Malay \\
\hline $\begin{array}{l}\text { P12 (participant } \\
\text { 12) }\end{array}$ & $36-45$ & Female & $\begin{array}{l}\text { Graphic } \\
\text { Designer }\end{array}$ & $16-20$ & $\begin{array}{l}\text { Creative } \\
\text { Industry }\end{array}$ & Malay \\
\hline
\end{tabular}

\section{Instrumentation}

After the determination of the study participants was done, the next step was to develop an interview protocol that contained semi-structured interview questions to help the researchers obtain the views of the study participants on the cross-cultural needs in corporate identity curriculum design. Research ethics were done at university level, and therefore involvement of all the study participants was on the basis of professionalism. The interview questions were confirmed by experts consisting of scholars with experience in graphic design education and curriculum development experts at the university level. Finally, the qualititative data obtained through the interview sessions were transcribed and analyzed thematically. 


\section{Data Analysis Process}

Thematic analysis involves the search for the required data based on the data obtained through interviews and has undergone six main steps in the process of analyzing data [29]. The process of analyzing the data in this study is as follows:

Step 1: Understand the Data Collected

Interview data were recorded and transcribed to identify the required data. After the interview results were transcribed, the data were also reviewed and agreed upon by the study participants.

\section{Step 2: Code Generation}

Generation of initial codes and open coding (open coding) was done to generate initial codes that have been found as a result of the implementation of the interview. The generation of these initial codes was an initial translation of the researchers that was felt to be appropriate.

Step 3: Classify the Data

The initial codes found were classified by category prior to form themes.

Step 4: Theme Formation

The formed themes were based on the initial codes which have been classified by category.

Step 5: Define and Name the Theme

Define and refine each theme to illustrate the essence of the data.

Step 6: Generate Data Reporting

Write data findings.

\section{Procedures of the Study}

Study procedures involved several data collection processes. The first was to identify the experts involved as study participants. The next step was to obtain permission and an appointment to conduct the interview session. Meetings with study participants were conducted at different time and places because participants had their own commitments too. All interviews were visual and audio recorded to facilitate transcription processes. Finally, transcription was aided using the NVIVO software 12 Pro version. Interview data were recorded and transcribed using NVIVO software. After the interview results were transcribed, the data was also reviewed and agreed upon by the study participants. The next step was generating initial codes. Open coding was done to generate the initial codes. A total of 198 codes were extracted from the interview data. Initially, each code was defined and then refined. Next, 16 categories were redefined and arranged under the categorically. Next, the researchers further detailed the arrangement of these initial codes into 16 categories to develop appropriate themes and sub-themes.

\section{Result and Discussion}

The results of the interview analysis identified three main themes were as the themes and sub-themes identified were stated in the Table 2. 
Table 2: Themes and Sub-Themes Derived in Needs Analysis Phase

\section{THEMES SUB-THEMES}

Theme 1:

Design features with ii) Cross-culture inspires new ideas
local culture identity

\begin{tabular}{|c|c|c|}
\hline \multirow[b]{2}{*}{$\begin{array}{l}\text { Theme 2: } \\
\text { Cross-cultural } \\
\text { curriculum }\end{array}$} & \multirow[b]{2}{*}{ based } & i) Curriculum design based on experiential learning \\
\hline & & ii) Cross-culture integration in corporate identity \\
\hline \multirow{4}{*}{$\begin{array}{l}\text { Theme 3: } \\
\text { Education based } \\
\text { holistic approach }\end{array}$} & \multirow{4}{*}{ on a } & i) Learning cross-cultural identity \\
\hline & & ii) Mastery of theory and practice \\
\hline & & iii) Project-based learning \\
\hline & & $\begin{array}{l}\text { iv) Assessment based on academic and industrial } \\
\text { standard }\end{array}$ \\
\hline
\end{tabular}

\section{Theme 1: Design Features with Local Culture Identity}

Based on the interviews conducted with the 12 study participants, it was found that cross-cultural needs ought to be applied to the production of graphic designs such as corporate identity. This is because cross-cultural designs highlighted the uniqueness of designs characterized by local identity. Local identity in designs needed to be created in order to be accepted by public and industries (Chu, 2016). Therefore, the design should be able to elevate the popularity of local culture in the eyes of the world. Based on the interview, there were some study participants who emphasized that:

a) cross-cultural is very important in the design medium so that designs become more versatile or adapted according to the situation or environment.

b) cross-cultural design concepts could highlight local identity as the strength of design presentation

c) cross-cultural provide good competitiveness to other design concepts as designs become more versatile and comprehensive, rather than focusing on producing one design feature.

For example, an experienced professional designer from the industry, (Participant 11) explained:

Because what..because from there if we do not cross-culture..we can not .. what people say..can produce a aa design,.. design that is versatile or comprehensive compared to us only.. aaa.. focus on only one(design feature)

(P11: Line 26 - 28)

It seemed that majority of the study participants agreed to the application of cross-cultural arts elements in the production of a design and sub-themes. The results are as follows:

\section{Sub-theme 1: Application of Cross-cultural Arts Elements}

Diversity of races and religions found in Malaysia has sparked various art forms in a culture. Therefore, some study participants stated that this cross-cultural art element is an advantage which could be used as a form of generating creative ideas in the production of a design, especially in the field of graphic design. 
(Participant 3) stated:

They (students)will be more creative when these cultural elements are combined. This will have a more harmonious impact. (P3: 55 - 56)

Whereas, (Participant 1) explained:

Designers need to understand how culture works in society because we create our visuals here using a local context, which means new local culture can sell. We can't use the overseas context to sell locally ... we can't. So for designers and for students in fact, understanding the cultures that exist in Malaysia is very important. (P1: 45 - 47)

Furthermore, elements of cross-cultural art which do not touch on racial and religious sensitivities could be used to produce designs that feature local identity (Philip, 2018). In addition, (Participant 10) also stated about the importance of cross-cultural in a multi-racial local. Based on interviews with the study participants who were experienced as lecturers in public and private institutions of Higher Learning as well as professional graphic designers, all the participants agreed with the cross-cultural application in the production of a design especially in graphic design. Moreover, several participants emphasized the importance and needs of cross-cultural in the field of design such as in corporate identity. Indeed, one of the expert views that injecting elements of cross-cultural was necessary for producing design to meet current needs.

This was showed in the statements presented by (Participant 9):

I think it is a MUST..okay (child)..so that we remain relevant..okay! Means that as a designer, no matter whether it is corporate identity or other design discipline in the graphic design, here is the cross culture ... okay.

(P9: Lines 238 - 239)

Another point was that the views from graphic designers were also important in terms of looking at cross-cultural needs in the production of graphic design. According to Expert 12, the application of cross-cultural art elements in design would produce designs which could adapt and innovate according to the situation or environment.

\section{Sub-theme 2: Cross-culture Inspires New Ideas}

Next, the majority of study participants also argued that cross-cultural could trigger and inspire new ideas in the production of designs and therefore lead to the production of designs which have their own identities. Cross-culture inspires new ideas on creating the design (Dong Yeong Lee \& Waller, 2016). The participants also explained clearly that the integration of cross-cultural contexts could assist in the proliferation of new ideas in inspiring creative designs as well as being able to meet with the current industry needs. The result of crosscultural design will have an interesting impact because there is a combination of various elements of cultural arts.

For example, (Participant 1) viewed that:

Yes..I think that when there is a integration of two or more cultures then we will be able to see something interesting and such things that have never been seen will likely to happen. As a result, we (people in the industry) are excited about the results or findings of the integration (P1: Lines 74 - 75) 


\section{Theme 2: Cultural-based Curriculum}

In addition, the majority of the study participants also agreed that there was a need to develop cross-cultural based curriculum design for the Graphic Design Program. According to the participants involved, they were of the view that cross-cultural elements should be applied in education, especially for programs involving graphic designs because the crosscultural based curriculum will meet the needs of creative industries. (Participant 2) argued that cross-cultural curriculum design should be developed so that students could understand more about cultural diversity of the nation.

Emmm..maybe we can practice an arrr program or special course for cross-cultural (P2: Line 105)

Moreover, the study participants further stated that the implementation of cross-cultural based curriculum would provide good learning experiences for students to increase their understanding about the various cultures; and this move eventually could generate a variety of ideas in the production of designs. It is hoped that with the integration of the cross-cultural in the field of arts education would guide students to produce designs that could meet the needs of society because the objective of design production is to convey information that is effective and accepted by the target group. It could be seen that various views were given by the participants with regards to cross-cultural based curriculum design and to conclude there were two sub-themes found namely:

\section{Sub-theme 1: Curriculum Design based Learning Experience}

Firstly, based on the findings, it could be summarized that the development of curriculum design in the Graphic Design Program should be based on curriculum concepts. Basically, the development of a graphic design curriculum should focus on learning outcomes, emphasize mastery and competence in terms of three essential of understanding, design skills and techniques, also creative thinking (D'Amico, 2018). Essentially, several of the study participants were of the view that mastery in the form of understanding and skills in the production of designs is obtained through the application of doing collaborations with the industry where students would be given opportunities to undergo actual practical training in the relevant industries. It is believed that industry involvement in the development of Graphic Design curriculum could assist in creating and training prospective graduates who could then meet the current needs of the industry (Dziobczenski et al., 2018). In other words, industry involvement will create the impacts of producing graduates who are able to meet the needs of the creative industries locally and globally, which would lead to graduates who are ready to take on the duties and responsibilities as a graphic designer in the real world.

According to (Participant 9), the industry's involvement in the development of Graphic Design curriculum is with the aim to ensure that the courses offered to students are relevant and be able to meet the current needs. In addition, the implementation of practical training in the industry can expose graduates to gain a lot of real experiences, give them the networking and able to fulfil the needs of industries (Chiang et al., 2018). This impact would lead towards improving the quality of learning outcomes. Overall, it could be summarized that an appropriate curriculum design can provide a good learning experience and enhance the creative thinking skills in order to produce a new design with cross-culture art elements.

Furthermore (Participant 5) argued: 
Our students ummm..are maybe a bit advanced in terms of technology..they have skills in the use of aaa specific software but in the production of ideas..design design..they need to have a new subject or curriculum that helps them to learn further or be taught in such areas (P5: Lines 76 - 78)

In addition, the curriculum design should expose students to graphic design work that implemented in the real creative industries, so that students can master knowledge with regards to producing effective and creative designs.

\section{Sub-theme 2: Cross-cultural Integration in the Corporate Identity Curriculum}

It seemed that the agreement towards cross-cultural integration should be considered in developing a corporate identity curriculum design. This is because the study participants felt that cross-cultural should be exposed to students from the early stages of design-based learning. Moreover, (Participant 2) expressed the view that she agreed to the development of cross-cultural corporate identity design. However, she suggested that planning research should be carried out to implement this curriculum. This is because cross-cultural involves cultural diversity and it requires in-depth research in order to develop a cross-cultural corporate identity curriculum design.

\section{Theme 3: Education based on a Holistic Approach}

Summarily, based on the findings it could be said that lecturers and graphic designers have provided a variety of views in terms of the teaching and learning methods for crosscultural corporate identity curriculum. A teaching method is a collection of actions that educators employ in order to instruct students and the technique within an approach is referred to as a method (Husaian et al., 2021). Based on the interviews conducted, it was found that education based on a holistic approach is suitable to be implemented in crosscultural corporate identity curriculum design. Student-centered teaching and learning would provide a platform to give out effective learning experiences to students such as mastering high levels of understanding and acquisition of skills.

For example, (Participant 12) who is experienced in the field of graphic design commented that:

Then in terms of one's attitude..err..attitude. So if you want to produce a design, the important one is the attitude because when he understands it, he can do it. for me..in my point of view. Attitude because when you want to process a logo..a design..the designer must have an attitude that what people say aa here understand and aaa there is an observer..the basis. If not when we give a task, when we give something.. he will not understand what.. why there is a need to do that thing.. why need that thing (P12: Lines 118 - 122).

Based on the findings from the interviews, it could be summarized that there are four main sub-themes to explain the teaching and learning methods of cross-cultural corporate identity, namely:

\section{Sub-theme 1: Exploration in Cross-cultural Identity Learning}

The participants were of the view that exploration in learning is an appropriate method to be implemented in the cross-cultural corporate identity curriculum. This exploration is in the form of a study analysis before a project or design is implemented. Some study participants suggested that the production of research in the design process should 
begin with reading from scientific materials. It could be seen that the majority of lecturers and graphic designers interviewed illustrated that the design process is an important component in the production of a design. In addition, two study participants suggested that field studies should be conducted by conducting interviews while one study participant was of the view that case studies should be implemented in cross-cultural learning.

Next, (Participant 6) stated that:

Research...he needs to look for research..he needs maybe there is field work..field research..go to see about ok why this house is like this so he can simplify it and then why he wears this kind of color. I think field research is better (P6: Lines 103 - 105)

Whereas (Participant 8) commented that:

Chances are they can do research by going to a place..meet people..see for yourself..more independent

(P8: Lines 94 - 95)

\section{Sub-theme 2: Mastery of Theory and Practice}

According to a few participants, the theoretical and practical aspects implemented in teaching and learning should be appropriate to the design medium to be produced. Apart from that, balance in mastering theoretical and practical aspects is important in order to improve students' understanding of producing a design. In total, seven study participants stated the importance of Gestalt theory which is the formation of the basis of understanding in producing a design. Apart from Gestalt theory, there are two other theories namely semiotic theory and semantic theory which have been explained by four study participants. The three theories stated by the respondents are theories that are commonly applied in learning to understand the production of a design. Every design needs to focus on theoretical aspects so that it looks more effective.

For example (Participant 1) argued:

If you want to apply Gestalt principle of course. If graphics should not run away from the Gestalt principle

(P1: Line 161)

He furthermore added:

The most important theory..I think..I think..aaa..if you study first of course it is the most basic.semiotic ahh..this semiotics causes us to symbolize, iconize from real objects (P1: Lines 157 - 158)

In addition, (Participant 5) also agreed that gestalt theory and semiotic theory are needed in design production learning:

Gestalt theory and then semiotic theory.. (P5: Line 123)

\section{Sub-theme 3: Project-based learning}

It could also be seen that almost all the study participants suggested that this crosscultural corporate identity curriculum be implemented at the diploma level because through a lot of exposures from the aspects of understanding and technical aspects could be conveyed in learning to produce a design. The majority of study participants suggested towards the usefulness of project-based learning in the Graphics Design Program curriculum. This is 
because project-based teaching and learning would provide a learning experience to produce designs based on the design process such as sketching ideas, design concept, composing a good layout arrangement and mastering of technical aspects such as applying of graphic software skills by using computer technology (Riyanti et al., 2019). Several study participants suggested that a few project-based tasks in learning such as packaging design and creating the symbol for logo design. Finally, in terms of assignments or projects that are proposed for cross-cultural corporate identity curriculum design development, the study participants also suggested on emphasizing the importance of conducting in-depth research on assigned tasks, implementing design processes, conducting academic visits and also encouraging the use of technology in learning. According to (Participant 5) there are many tasks that could be given to students related to cross-cultural corporate identity including packaging design, poster design, postcard design and more.

She commented:

Typography, packaging, posters..poster design, calligraphy..what is a greeting card..aaa many corporate identities lahhh...(P5: Line 136)

\section{Sub-theme 4: Assessment Based on Academic and Industrial Basic Standards}

The proposed form of evaluation based on a given task is intended to test the understanding and mastery of skills in producing a design. Some study participants stated that the evaluation conducted was to assess the understanding of the basics of design production such as knowledge of design elements and principles, mastery of skills and look at the design process that has been produced. Therefore, the evaluation conducted on project-based assignments would be evaluated according to the criteria of basic academic standards in the Graphic Design Program (Giloi \& Du Toit, 2013). In addition, there were several study participants who suggested the involvement of people from the industry as well as outsiders who have expertise in the design field should be invited to evaluate students' project. The involvement of the people from the industry as well as design experts is needed to provide constructive comments on students' project. This effort and strategy is one of the most beneficial forms of knowledge sharing. In addition, students would be able to get good and comprehensive input on the production of designs produced. In fact, students would also gain a better understanding of reality in order to produce a design.

To conclude, (Participant 3) commented:

Usually, there is the involvement of external examiners because it is a basic practice (P3: Line 146)

Summarily, this could mean that industry involvement should be of importance for Graphic Design Programs. This means that the basic practice to produce effective designs and good graduates that fulfil the needs of industry is to collaborate and build networking with the industry itself. Apart from that, teaching and learning method should not just rely on the standards set by academicians but also involve professionals from the industry. From the aspects of evaluating the task or project, the findings of the study indicated that evaluation should be conducted to assess understanding level and performance of skills holistically.

\section{Conclusion}

It could be concluded that the proposed development of a cross-cultural corporate identity design curriculum in the Graphic Design Program was supported and approved by 
almost all lecturers and graphic designers who collaborated as study participants in this research. This study focuses on the cross-cultural corporate identity design curriculum as a component in the graphic design curriculum. Cross-culture is seen as very important in the Malaysian context because understanding culture is one of the ways for our country to maintain peace and unity. Overall, it can be concluded that cross-cultural giving has a positive impact in the field of design such as being able to generate high creativity, able to generate various concepts based on culture and produce a variety of new designs that are unique and able to highlight on local identity. Elements such as local culture, local identity, colours in culture, local motifs and patterns are among those that have been explained by the study participants during the interview sessions in relations to cultural elements in the production of designs such as when designing the corporate identity items. Moreover, the findings in this study showed that all the study participants have suggested the use of elements from the local culture to be used in producing a design such as in corporate identity. It is suggested that the designs that apply cross-cultural elements would look more unique.

In addition, a cross-cultural corporate identity curriculum can contribute towards the development of a better Graphic Design Program. This new curriculum is a platform to prepare students to penetrate easily into the job market in the industry. In addition, this cross-cultural corporate identity curriculum is seen to open many opportunities for students to learn various forms of knowledge disciplines in design. Certainly, culture is another area that can be applied in design. Meanwhile, with a good understanding of culture, this situation would help to generate new ideas that are still fresh and the designs produced can be accepted by all walks of life. Thus, cross-cultural context is seen to be able to open the minds and eyes of students to produce natural ideas without plagiarizing from various sources. Designs would also look unrestrained and be able to provide great competition to designs at international level. Hence, it could be clearly seen that there is a need to develop crosscultural corporate identity curriculum design in the Graphic Design Program. Eventually, with all the in-depth information gathered through this analysis phase, the knowledge would contribute as a guide to design a cross-cultural corporate identity curriculum model for the Graphic Design Program in local higher learning institutions. It is hoped that the development of a cross-cultural curriculum model could also empower students to master high skills on the use of digital technology in the production of design in line with $5^{\text {th }}$ Industrial Revolution. In fact, this empowerment would further produce future graphic designers who are competitive and able to meet the needs of the creative industry globally.

\section{Acknowledgements}

This study is funded by Tabung Kokurikulum PTJ, Faculty of Education, Universiti Kebangsaan Malaysia, grant no. GG-2021-015. The authors would like to express gratitude to various parties, especially the professional graphic designers and lecturers from industries and academic institutions for supporting this research.

\section{References}

Ahmad, J., \& Weerakkody, N. (2011). Komunikasi budaya silang, kompetensi, pengajaran dan pembelajaran : satu analisis. Jurnal Pendidikan Malaysia, 36(1), 45-53.

Al-hamlan, S. (2015). A Needs Analysis Approach to EFL Syllabus Development for Second Grade Students in Secondary Education in Saudi Arabia: A Descriptive Analytical Approach to Students' Needs Professor Abdallah Ahmad Baniabdelrahman, PhD. American International Journal of Contemporary Research, 5(1), 118-145. 
Austerlitz, D. N., Blythman, D. M., Jones, B. A., Jones Ann, C., Grove-White, A., Morgan, P. S. J., Orr, S., Shreeve, A., \& Vaughan, P. S. (2008). Mind the gap: expectations, ambiguity and pedagogy within art and design higher education. The Student Experience in Art and Design Higher Education: Drivers for Change, 125-148.

Blair-early, A. (2010). Beyond borders: Participatory design research and the changing role of design. Global Interaction In Design, Special issue Visible Languange 44.2, 207-218.

Bocanegra-Valle, A., \& Table. (2016). Need Analysis For Curriculum Design. In The Routledge Handbook of English for Academic Purposes. https://doi.org/10.4324/978131565745531

Chiang, W. S., Idris, M. Z. bin, \& Tan Wee Chuen. (2018). What Makes An Undergraduate Graphic Design Education Valuable? Journal of Education and Social Sciences, 11(1), 7382.

Chu, S. (2016). Design Factors Affect User Experience for Different Cultural Populations. Journal of Educational Issues, 2(2), 307-319. https://doi.org/10.5296/jei.v2i2.10217

D'Amico, G. S. (2018). Key Managerial Skill Sets in Graphic Design Education. Visual Communication Journal, 54(2).

Dalib, S., Harun, M., Yusof, N., \& Ahmad, M. K. (2019). Exploring intercultural competence among students in Malaysian campuses. Jurnal Komunikasi: Malaysian Journal of Communication, 35(1), 1-16. https://doi.org/10.17576/JKMJC-2019-3501-01

Drucker, J. (2016). Knowledge Design. The Journal of the Design Studies Forum, 7075(February). https://doi.org/10.2752/175470814X13823675225117

Dziobczenski, P. R. N., Person, O., \& Meriläinen, S. (2018). Designing career paths in graphic design: A document analysis of job advertisements for graphic design positions in finland. Design Journal, 21(3), 349-370.

https://doi.org/10.1080/14606925.2018.1444874

Foroudi, P., Melewar, T. C., \& Gupta, S. (2017). Corporate Logo: History, Definition, and Components. International Studies of Management and Organization, 47(2), 176-196. https://doi.org/10.1080/00208825.2017.1256166

Fraher, R., \& Martinson, B. (2011). Process and pedagogy in undergraduate graphic design education. Design Journal, 14(4), 390-412. https://doi.org/10.2752/175630611X13091688930372

Giloi, S., \& Du Toit, P. (2013). Current Approaches to the Assessment of Graphic Design in a Higher Education Context. International Journal of Art and Design Education, 32(2), 256268. https://doi.org/10.1111/j.1476-8070.2013.01758.x

Gray, C. M., \& Boling, E. (2017). Designers' articulation and activation of instrumental design judgements in cross-cultural user research. Analysing Design Thinking: Studies of CrossCultural Co-Creation, 191-211. https://doi.org/10.1201/9781315208169

Grethe, A., \& Pedersen, J. (2016). Corporate identity in a globalised world : A study of elements marking national identity on company websites. 45, 28-45.

Hie, Y. H., Samsu, K. H. K., Adnan, Z. H., Awang, M. D., \& Halim, A. A. (2018). Peranan Guru Sebagai Agen Sosialisasi dalam Membentuk Perpaduan Kaum di Sekolah. Akademika, 88(2), 95-108.

Hoyos, C. M., Scharoun, L., \& Poplin, J. (2015). the Importance of Cross-Cultural Learning in the Design Disciplines: a Case Study Reviewing a Series of Short Term Study Tours Designed To Support Cross-Cultural Exchange in the Asia-Pacific Region. International Journal of Arts \& Sciences, 08(05), 435-442.

Husaian, K., Wahab, P. A., Musa, M. N. H., \& Ngatli, H. A. (2021). Pedagogical Practices of 
Sustainability and Society Course Delivery in Higher Education. Akademika 91(Isu Khas), 91, 119-129. https://doi.org/https://doi.org/10.17576/akad-2021-91/K-11 Pedagogical Ibrahim, A. (2016). Definition Purpose and Procedure of Developmental Research: An Analytical Review. Asian Research Journal of Arts \& Social Sciences, 1(6), 1-6. https://doi.org/10.9734/arjass/2016/30478

Inciong, A. (2010). Graphic Design Education: Pedagogy and Research Methods. 3Rd International Conference of Education, Research and Innovation (Iceri2010).

Lee, D., \& Bain, J. (2016). Developing a Cross-Cultural Design Methodology: A study of UKSouth Korean Collaboration in Higher-Education Design. The Global E-Learning Journal, $5(2)$.

Lee, D. Y., Ha, J. Y., \& Fairfax, D. (2016). Cross-cultural design (CCD) learning reflective tool based on UK and Korea's collaborative design projects. Proceedings of International Design Conference, DESIGN, DS 84(Ccd), 2091-2100.

Lee, Yeong, D., \& Waller, M. (2016). Cross-cultural design learning tool: Cross-cultural design (CCD) approach: A study of South Korean student projects in collaboration with Goldsmiths, university of London, UK. Lecture Notes in Computer Science (Including Subseries Lecture Notes in Artificial Intelligence and Lecture Notes in Bioinformatics), 9741(Ccd), 89-97. https://doi.org/10.1007/978-3-319-40093-8_10

Meyer, M. W., \& Norman, D. (2020). Changing Design Education for the 21st Century. She Ji: The Journal of Design, Economics, and Innovation, 6(February), 13-49. https://doi.org/10.1016/j.sheji.2019.12.002

Meyer, R. J. (2008). Culture, context, and communication: Developing a culturally sensitive curriculum in graphic design education [lowa State University]. https://search.proquest.com/openview/3b877c2e8a22c945070a7e8a22e132a0/1?pqorigsite $=$ gscholar $\& \mathrm{cbl}=18750 \&$ diss $=y$

Murdoch-Kitt, K., \& Emans, D. (2014). Design Nexus: integrating cross-cultural learning experiences into graphic design education. Studies in Material Thinking, 11(November 2016), 1-24. https://www.materialthinking.org/sites/default/files/papers/SMT_Vol 11_Paper 04_Murdoch-Kitt.pdf

Nordin, N. M. M. H. N. (2018). Cross-culture learning via massive open online courses for higher education. Jurnal Pendidikan Malaysia (Malaysian Journal of Education), 43(1), 35-39.

Offorma, G. C. (2016). Integrating components of culture in curriculum planning. International Journal of Curriculum and Instruction, 8(1), 1-8.

Orr, S., and Shreeve, A. (2018). Art and design pedagogy in higher education: knowledge, values and ambiguity in the creative curriculum.

Orr, S., Yorke, M., \& Blair, B. (2014). The answer is brought about from within you: A studentcentred perspective on pedagogy in art and design. International Journal of Art and Design Education, 33(1), 32-45. https://doi.org/10.1111/j.1476-8070.2014.12008.x

Ozkaynak, M. G., \& Ust, S. (2012). New forms of Design Education. Procedia - Social and Behavioral Sciences, 51, 140-143. https://doi.org/10.1016/j.sbspro.2012.08.133

Philip, L. (2018). Exploring the Role of Culture on Graphic Designs. International Journal of Trend in Scientific Research and Development, Volume-2(Issue-3), 424-435. https://doi.org/10.31142/ijtsrd10857

Rashed, Z. N., Tamuri, A. H., Ihwani, S. S., Ilias, M. F., \& Yahaya., M. (2020). Model Kurikulum Integrasi dalam Kurikulum Pendidikan Islam. ISLĀMIYYĀT 42(Isu Khas) 2020: 51 - 58, 42(0), 51-58. https://doi.org//doi.org/10.17576/islamiyyat-2020-42IK-07) 
Richey, R. C., \& Klein, J. D. (2005). Developmental research methods: Creating knowledge from instructional design and development practice. Journal of Computing in Higher Education, 16(2), 23-38. https://doi.org/10.1007/BF02961473

Richey, R. C., Klein, J. D., \& Nelson, W. A. (2004). Developmental research: Studies of instructional deisgn and development. Handbook of Research on Educational Communications and Technology., 1099-1130. https://doi.org/10.1007/978-1-46143185-5_12

Riyanti, M. T., Erwin, T. N., \& S.H, S. (2019). Implementing Project Based Learning Approach to Graphic Design Course. International Journal of Research-Granthaalayah, 7(7), 432440. https://doi.org/10.5281/zenodo.3370494

Sahrir, M. S., Alias, N. A., Ismail, Z., \& Osman, N. (2012). Employing design and development research (DDR) approaches in the design and development of online arabic vocabulary learning games prototype. Turkish Online Journal of Educational Technology, 11(2), 108119.

Spencer, J. (2016). Design Week30 John Spencer: "Universities aren' $t$ the future of design education ". Design Week. https://www.designweek.co.uk/issues/21-27-november2016/john-spencer-universities-arent-future-design-education/

Thiruvengadam, P. (2014). A Need For Needs Analysis. International Journal of Applied Research \& Studies ISSN, II(Issue 1/Jan), 1-6.

Yang, C.-M., \& Hsu, T.-F. (2017). New Perspective on Visual Communication Design Education: An Empirical Study of Applying Narrative Theory to Graphic Design Courses. International Journal of Higher Education, 6(2), 188. https://doi.org/10.5430/ijhe.v6n2p188

Yunus, M. M., Nasir, N. M., \& Samsudin, N. H. (2019). Malaysian national day logo 2018: An analysis based on the theory of arts and visual communication. Jurnal Komunikasi: Malaysian Journal of Communication, 35(2), 176-194. https://doi.org/10.17576/JKMJC2019-3502-11 